\title{
KELIMPAHAN BULU BABI (SEA URCHIN) PADA KARANG MASSIVE DAN BRANCHING DI DAERAH RATAAN DAN TUBIR DI LEGON BOYO, PULAU KARIMUNJAWA, TAMAN NASIONAL KARIMUNJAWA
}

\author{
Rizqi Waladi Purwandatama, Churun A'In, Suryanti ${ }^{I}$ \\ Program Studi Manajemen Sumberdaya Perairan, Jurusan Perikanan \\ Fakultas Perikanan dan Ilmu Kelautan, Universitas Diponegoro
}

\begin{abstract}
ABSTRAK
Bulu babi (sea urchin) merupakan spesies kunci bagi ekosistem terumbu karang. Menurunnya populasi bulu babi diduga akan menyebabkan matinya terumbu karang karena populasi mikroalga akan meningkat dengan drastis sehingga mikroalga akan mendominasi menutupi karang. Oleh sebab itu, dengan mengamati kelimpahan bulu babi, persentase penutupan karang, dan faktor-faktor yang mempengaruhi kehidupan bulu babi dapat diketahui apakah perairan tersebut masih stabil atau telah rusak sehingga keseimbangan ekosistem di wilayah perairan tersebut dapat terjaga. Tujuan penelitian ini adalah untuk mengetahui kelimpahan bulu babi (sea urchin) pada karang massive dan branching di daerah rataan terumbu karang dan tubir di Legon Boyo, Pulau Karimunjawa, Balai Taman Nasional Karimunjawa. Metode sampling yang digunakan dalam pengambilan data penutupan karang adalah line transek. Adapun pengambilan data kelimpahan bulu babi menggunakan kuadran transek yang berukuran 1 x $1 \mathrm{~m}$. Penelitian ini dilakukan pada dua lokasi yaitu stasiun A (rataan terumbu) dan stasiun B (tubir). Panjang line transek adalah 50 meter yang di letakkan sejajar garis pantai, transek yang digunakan di daerah rataan terumbu sebanyak 3 line dan daerah tubir sebanyak 3 line. Jarak antara line di masing-masing lokasi sampling $5 \mathrm{~m}$. Nilai persentase penutupan karang hidup di daerah rataan terumbu sebesar $66,36 \%$. Sedangkan nilai persentase penutupan karang hidup di tubir sebesar 73,00 \%. Nilai tersebut termasuk dalam kategori baik. Pada rataan terumbu didapatkan kelimpahan individu bulu babi sebanyak 426 ind/150 m², Sedangkan untuk kelimpahan individu bulu babi pada tubir yaitu sebanyak $193 \mathrm{ind} / 150 \mathrm{~m}^{2}$. Nilai signifikasi uji Independent $T$ Test yang didapat adalah 0,008 sehingga $0,008 \leq 0,05$. Ini berarti $\mathrm{H}_{1}$ diterima yang berarti terdapat perbedaan pada jumlah bulu babi pada karang massive dan karang branching.
\end{abstract}

Kata Kunci: Kelimpahan Bulu Babi, Karang Massive, Karang Branching, Rataan Karang, Tubir Karang.

\section{ABSTRACT}

Sea urchin is a keystone species for coral reef ecosystem. Decreasing populations of sea urchins will supposedly causing the death of coral reefs because the microalgae populations will rise dramatically so that microalgae will dominate the coral cover. Therefore, the observed abundance of sea urchins, coral cover, and the factors that affect the lives of sea urchins can be known these waters are still stable or has been damaged so that the balance of aquatic ecosystem can be maintained. This study aims to determine the abundance of sea urchins in massive and branching coral on the reef flat and reef slope at Legon Boyo, Karimunjawa Island, Karimunjawa National Park. The method used in this study is a descriptive survey method. Sampling methods used in coral cover data retrieval is line transect. The sea urchin abundance data retrieval using transect quadrant measuring $1 \times 1 \mathrm{~m}$. This research was conducted at two locations: Station A (reef flat) and station B (reef slope). Transect line length is 50 meter in place parallel to the coastline, transects were used in the reef flat area as much as 3 line and the slope of the area as much as 3 line. Line distance between sampling locations in each of $5 \mathrm{~m}$. The results showed that the percentage of live coral cover on the reef flat area of $66,36 \%$. While the percentage of live coral on the reef slope of $73,00 \%$. This value is included in both categories. Obtained on the abundance of individual sea urchins on reef flat much as $426 \mathrm{ind} / 150 \mathrm{~m}^{2}$, as for the abundance of individual sea urchins on the reef slope of as many as $193 \mathrm{ind} / 150 \mathrm{~m}^{2}$. Independent $\mathrm{T}$ test significance value obtained Test is 0.008 so $0.008 \leq 0.05$. This means that $\mathrm{H} 1$ is accepted which means that there is a difference in the number of sea urchins in massive corals and branching corals.

Keywords: Abundace of Sea Urchins, Massive Coral, Branching Coral, Reef Flat, Reef Slope.

*) Penulis Penanggung Jawab 


\section{A. Pendahuluan}

Gugusan terumbu karang yang terdapat di Kepulauan Karimunjawa termasuk ke dalam gugusan terumbu karang tepi. Terdapat 63 genera dari 15 famili karang keras berkapur (scleractinia) dan tiga genera nonscleractinia yaitu Millepora dari kelas Hydrozoa, Heliopora dan Tubipora dari kelas Anthozoa. Penutupan karang keras berkisar antara 6,7 \% - 68,9 \% dan indeks keragaman berkisar antara 0,43-0,91. Kondisi terumbu karang di Kepulauan Karimunjawa secara umum mempunyai rata-rata penutupan sekitar $40 \%$ (Wildlife Conservation Society, 2004).

Menurut Nybakken (1992), ekosistem terumbu karang ialah salah satu ekosistem yang paling kompleks dan khas di salah satu daerah tropis. Produktivitas dan keanekaragaman yang tinggi merupakan sifat dari ekosistem ini. Perpaduan dalam keseimbangan dari bentuk-bentuk kehidupan yang ada menghasilkan panorama yang bernilai estetika tinggi.

Terumbu karang terbentuk dari endapan-endapan massive dari kalsium karbonat yang dihasilkan oleh fauna karang dengan sedikit tambahan dari alga berkapur dan organisme-organisme lain yang mengeluarkan kalsium karbonat $\left(\mathrm{CaCO}_{3}\right)$. Profil dan konfigurasi terumbu karang membuat topografi dasar perairan menjadi spesifik disertai bentuk-bentuk pertumbuhan karang batu yang sangat bervariasi merupakan tempat ideal bagi asosiasi berbagai biota laut, menjadikannya lebih bernilai dan unik (Lalamentik dan Rembet 1996).

Terumbu karang merupakan habitat (tempat hidup) bagi berbagai ikan maupun biota non ikan yang diantaranya memiliki nilai ekonomis tinggi.Karena itu, habitat ini merupakan salah satu sumber pangan bagi umat manusia. Biota non-ikan yang ditangkap atau diambil di daerah terumbu karang diantaranya: Bulu Babi (Echinodea), Kima (Tridacna, Hippopus), Lobster (Panulirus), Sotong (Sepia, Sepioeuthis), Teripang (Sea Cucumber), dll.

Salah satu biota yang berasosiasi di ekosistem terumbu karang adalah bulu babi. Bulu babi adalah salah satu biota yang termasuk ke dalam filum echinodermata yang tersebar dari daerah intertidal dangkal hingga ke laut dalam. Menurut Nystrom et al.,(2000), bulu babi merupakan salah satu spesies kunci (keystone species) bagi komunitas terumbu karang. Hal ini disebabkan bulu babi adalah salah satu pengendali populasi mikroalga. Mikroalga adalah pesaing bagi hewan karang dalam memperebutkan sumberdaya ruang (sinar matahari). Salah satu jenis bulu babi yang biasanya terdapat di ekosistem terumbu karang adalah dari genus Diadema, Namun menurut Sugiarto dan Supardi (1995), menyebutkan bahwa genus Diadema dianggap sebagai omnivora yang pada lingkungan berbeda jenis ini dapat beradaptasi dengan memakan polip dari karang. Menurut Aziz (1994a), beberapa genus bulu babi yang ditemukan di laut Indonesia antara lain Diadema, Tripneustes, Toxopneustes, Echinothrix, Echinometra, Lemnopleurus, Mespillia, dan Salmacis.

Tujuan dilakukannya penelitian ini adalah untuk mengetahui kelimpahan bulu babi (sea urchin) pada karang massive dan branching di daerah rataan terumbu karang dan tubir di Legon Boyo, Pulau Karimunjawa, Balai Taman Nasional Karimunjawa.

\section{B. Materi dan Metode Penelitian}

\section{Materi Penelitian}

Materi yang digunakan pada penelitian ini adalah bulu babi (sea urchin) yang ditemukan di daerah rataan dan daerah tubir pada karang massive dan karang branching di Legon Boyo, Pulau Karimunjawa, Taman Nasional Karimunjawa. Alat yang digunakan dalam penelitian ini yaitu Peralatan Scuba dan Masker Snorkel digunakan untuk alat bantu di bawah air. Pensil dan Kertas Anti Air digunakan untuk alat tulis di bawah air. Roll Meter digunakan sebagai line transek. Kuadran Transek digunakan untuk pengambilan data kelimpahan bulu babi. Secchi disc digunakan untuk mengukur kecerahan. Termometer air raksa digunakan untuk mengukur suhu permukaan laut dan suhu udara. Refraktometer digunakan untuk mengukur salinitas. Underwater camera digunakan untuk dokumentasi pengamatan lapangan. Current meter digunakan untuk mengukur arus. GPS (Global Positioning System) digunakan untuk penentuan plot sampling.

\section{Metode Penelitian}

Metode yang digunakan dalam pengambilan data sampel ada dua (2) tahap: yaitu pengambilan data penutupan karang dan pengambilan data kelimpahan bulu babi (sea urchin).

Pengambilan data penutupan karang dengan menggunakan metode line transek. Pengambilan data penutupan karang dilakukan dengan menggunakan cara sebagai berikut:

a. Memasang line transek yang telah ditandai dengan skala sepanjang 50 meter sejajar garis pantai dengan jarak antar line transek yaitu 5 meter;

b. Menghitung panjang karang hidup, karang mati, pecahan karang, dan substrat pada line transek yang telah dipasang;

c. Melakukan pengulangan sebanyak $3 \mathrm{x}$ pada masing-masing stasiun, stasiun A (daerah rataan) dan stasiun B (daerah tubir); dan

d. Mengidentifikasi jenis karang yang ditemukan dengan melihat buku panduan identifikasi karang (Carpenter and Volker, 1998) dan (Rahman et al., 2010). 
Tahap pengumpulan data selanjutnya adalah melakukan pengambilan data kelimpahan bulu babi (sea urchin). Pengambilan data kelimpahan bulu babi (sea urchin) dalam penelitian ini adalah sebagai berikut:

a. Observasi (survei) lapangan untuk menentukan lokasi sampling;

b. Plotting GPS;

c. Memasang line transek yang telah ditandai dengan skala sepanjang 50 meter sejajar garis pantai;

d. Memasang kuadran transek berukuran 1 x 1 meter yang diletakkan pada bagian tengah line transek; dan

e. Mengambil data kelimpahan bulu babi (sea urchin) di dalam frame kuadran transek berukuran $1 \times 1$ meter sepanjang 50 meter.

\section{Suhu}

Pengukuran parameter fisika dan kimia di lokasi penelitian adalah sebagai berikut:

Pengukuran suhu dalam penelitian ini dilakukan dengan menggunakan 2 buah thermometer air raksa dengan ketelitian $1^{\circ} \mathrm{C} .1$ buah thermometer digunakan untuk mengukur suhu udara, sedangkan 1 buah thermometer yang lain digunakan untuk mengukur suhu air.

2. Salinitas

Salinitas perairan dapat diukur menggunakan refraktometer yang dalam penggunaannya meneteskan air yang akan diukur salinitasnya pada ujung alat tersebut, kemudian melihat nilai skala salinitas yang tertera pada refraktometer.

3. Kecerahan

Pengukuran kecerahan badan air menggunakan alat yang dinamakan secchi disc. Alat ini berbentuk piringan yang terbuat dari seng atau pun besi yang dicat dengan warna hitam dan putih yang diikatkan pada tali atau tambang berskala.

4. Kedalaman

Kedalaman perairan di lokasi penelitian diukur dengan menggunakan tali atau tambang berskala dengan ketelitian $1 \mathrm{~cm}$.

5. Kecepatan arus

Kecepatan arus dapat diukur dengan menggunakan curent meter yang dalam penggunaannya adalah dengan mengapungkan alat ini di permukaan air dan mencatat jumlah putaran kipas yang terdapat pada alat ini.

6. $\mathrm{pH}$ atau derajat keasaman

$\mathrm{pH}$ atau derajat keasaman perairan yang diukur dalam penelitian ini menggunakan $\mathrm{pH}$ paper.

3. Metode Analisis Data

a. Penutupan Karang

Persentase penutupan karang hidup, karang mati, pasir dan pecahan karang, dapat dihitung dengan menggunakan rumus (Odum, 1993) berikut:

Dimana:

$$
\mathrm{C}=\frac{\boldsymbol{L} i}{L} \times 100 \%
$$

C : Persentase tutupan karang

$\mathrm{Li}$ : Panjang tutupan karang jenis ke-i

$\mathrm{L}$ : Panjang total transek

Menurut Dahuri et al., (2001), kriteria penilaian kondisi terumbu karang adalah berdasarkan persentase penutupan karang hidup dengan kategori sebagai berikut:

1. Kategori rusak : :0-25\%

2. Kategori sedang $: 25-50 \%$

3. Kategori baik $: 50-75 \%$

4. Kategori sangat baik : $75-100 \%$

b. Kelimpahan Bulu Babi

Menurut Odum (1993), kelimpahan bulu babi (sea urchin) dapat dihitung dengan menggunakan rumus berikut, yaitu:

Dimana:

$$
\mathrm{KR}=\frac{n i}{N} \times 100 \%
$$

KR : Kelimpahan individu

$\mathrm{N}$ : Jumlah total individu

$\mathrm{Ni}$ : Jumlah individu 


\section{c. Indeks Keanekaragaman (H')}

Keanekaragaman spesies dapat dikatakan sebagai indikasi banyaknya jenis makrobenthos dan bagaimana penyebaran jumlah individu pada setiap jenis dan lokasi sampling. Untuk menentukan keanekaragaman dihitung dengan menggunakan formula Shannon-Weaver (Odum, 1993) sebagai berikut:

$$
H^{\prime}=-\sum_{i=1}^{i} \mathrm{Pi} \ln \mathrm{Pi}
$$

Dimana:

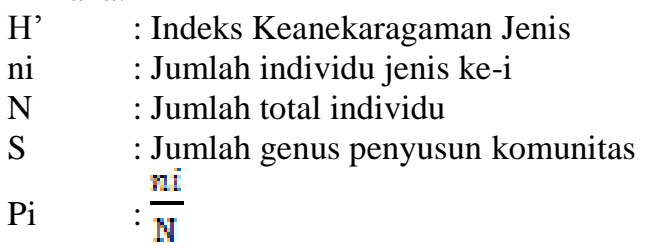

Kisaran stabilitas perairan berdasarkan indeks perairan tersaji dalam Tabel 1 berikut:

Tabel 1. Kisaran Stabilitas Perairan Berdasarkan Indeks Keanekaragaman.

\begin{tabular}{ccc}
\hline No. & Kisaran Stabilitas & Keanekaragaman \\
\hline 1. & $0<\mathrm{H}^{\prime} \leq 1$ & Rendah (tidak stabil) \\
2. & $1<\mathrm{H}^{\prime} \leq 2$ & Sedang \\
3. & $\mathrm{H}^{\prime}>2$ & Tinggi (stabil) \\
\hline
\end{tabular}

\section{d. Indeks Keseragaman (e)}

Keseragaman dapat dikatakan sebagai keseimbangan, yaitu komposisi individu tiap jenis yang terdapat dalam suatu komunitas. Untuk menghitung keseragaman jenis dapat dihitung dengan menggunakan rumus Evennes (Odum, 1993) berikut:

Keterangan:

$$
\mathrm{e}=\frac{H \boldsymbol{H}}{H \max }
$$

e : Indeks Keseragaman

H' : Indeks Keanekaragaman

$\mathrm{H}_{\max } \quad$ : Keanekaragaman spesies maksimum $(\ln \mathrm{S})$

Dimana:

e $<0,4 \quad$ : Tingkat keseragaman populasi kecil

$0,4<\mathrm{e}<0,6 \quad$ : Tingkat keseragaman populasi sedang

e $>0,6 \quad$ : Tingkat keseragaman populasi besar

e. Indeks Dominasi

Untuk menghitung indeks dominansi digunakan rumus Odum, (1993) sebagai berikut:

Dimana:

D : Indeks Dominansi

ni : Jumlah individu spesies ke- $\mathrm{i}$

$\mathrm{N} \quad$ : Jumlah total spesies

\section{f. Analisis Uji Independent T Test}

Penelitian ini mencoba mengkaji apakah pada 2 (dua) habitat (karang massive dan branching) terdapat perbedaan kelimpahan bulu babi. Uji analisis yang digunakan pada penelitian ini adalah menggunakan Uji Independent T Test dengan pengoperasian program SPSS 16. Menurut Hartono (2008), Uji Analisis Independent $T$ Test adalah uji statistik yang membandingkan dua kelompok yang berbeda atau membandingkan nilai rata-rata dua kelompok independent. Dengan keputusan adalah sebagai berikut:
a. Ho diterima apabila : Sig $>0.05$ (tidak signifikan)
b. Ha diterima apabila : Sig $<0.05 *$ (signifikan)
: Sig $<0.01 * *$ (sangat signifikan)

Dengan demikian, hipotesis dalam penelitian ini adalah sebagai berikut :

Ho : Tidak ada perbedaan kelimpahan bulu babi pada karang massive dan branching

$\mathrm{H}_{1} \quad$ : Terdapat perbedaan kelimpahan bulu babi pada karang massive dan branching 


\section{Hasil dan Pembahasan}

1. Hasil

\section{a. Deskripsi lokasi}

Pantai Legon Boyo terletak di wilayah Pulau Karimunjawa, Kepulauan Karimunjawa, Kabupaten Jepara, Jawa Tengah yang merupakan salah satu pantai yang menjadi jalur pelayaran kapal nelayan yang akan pergi melaut maupun yang akan berlabuh di dermaga dan TPI Karimunjawa. Pantai tersebut terdiri atas pasir putih dengan pecahan karang yang dapat dilihat dari bibir pantai hingga 50 meter menuju laut. Secara geografis, Pantai Legon Boyo memiliki kondisi perairan yang tenang, terdapat beberapa resort menghadap ke arah barat yang dibangun di pinggir pantai, dibangunnya beberapa KJA (Keramba Jaring Apung) dengan ikan kerapu sebagai biota budidaya-nya, serta terdapat lahan mangrove yang dijadikan tambak. Namun secara umum, pantai tersebut jarang dikunjungi oleh para wisatawan karena pantai tersebut menjadi jalur perjalanan kapal yang akan melaut maupun berlabuh di Pelabuhan Karimunjawa sehingga banyak karang di sekitar Legon Boyo mati dan patah karena terkena kapal penangkapan. Titik koordinat dari titik sampling yang dilakukan di Pantai Legon Boyo adalah $5^{\circ} 51^{\prime} 37,70^{\prime \prime}$ LS dan $110^{\circ} 25^{\prime} 30,22^{\prime}$ "BT untuk lokasi rataan terumbu karang dan $5^{\circ} 51^{\prime} 37,15^{\prime \prime}$ LS dan $110^{\circ} 25^{\prime} 28,46^{\prime \prime}$ BT untuk lokasi tubir karang.

\section{b. Presentase Penutupan Karang}

Data hasil pengamatan karang hidup di Legon Boyo, Pulau Karimunjawa, Taman Nasional Karimunjawa ditemukan 19 genus karang di lokasi penelitian. Ada pun data presentase penutupan karang hidup dan substrat dasar yang terdapat di lokasi penelitian dapat dilihat pada Gambar 1 berikut:

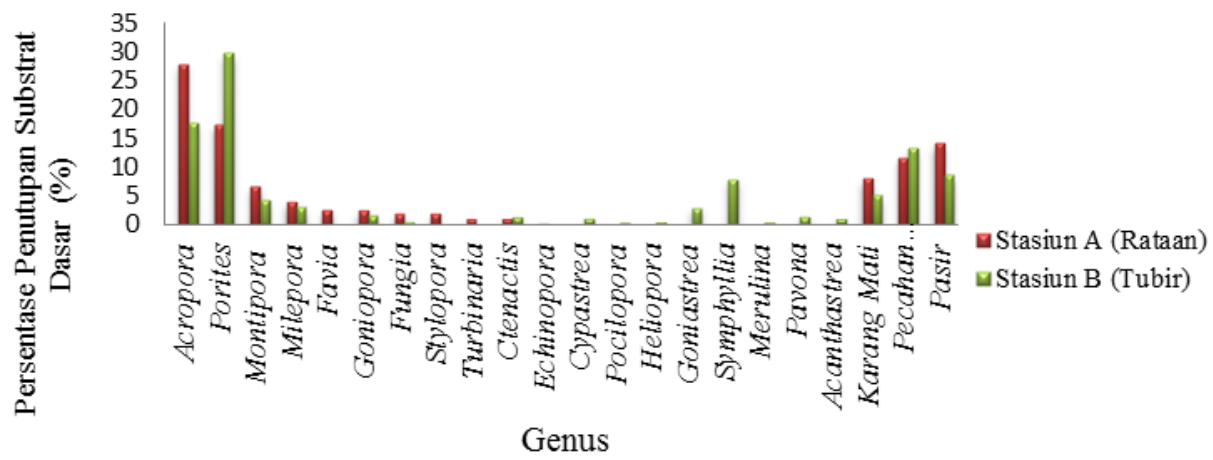

Gambar 1. Persentase Penutupan Karang Hidup

c. Nilai Indeks Keanekaragaman (H') Dan Indeks Keseragaman (E) Karang

Hasil perhitungan nilai indeks keanekaragaman $\left(\mathrm{H}^{\prime}\right)$ dan indeks keseragaman (e) di tiap stasiun di lokasi penelitian tersaji pada Tabel 2 berikut:

Tabel 2. Nilai Indeks Indeks Keanekaragaman (H') dan Indeks Keseragaman (e) di Tiap Stasiun

\begin{tabular}{cccc}
\hline No & Stasiun & H' & e \\
\hline 1 & A & 2,028 & 0,846 \\
2 & B & 2,353 & 0,849 \\
\hline
\end{tabular}

Sumber: Data Penelitian 2013

\section{d. Kelimpahan Komunitas Bulu Babi (Sea Urchin)}

Berdasarkan dari hasil pengumpulan data kelimpahan bulu babi (sea urchin) pada lokasi yang berbeda (Rataan Karang dan Tubir Karang), ditemukan 5 (lima)jenis bulu babi, yaitu Diadema setosum, Diadema antilarum, Echinthrix calamaris, mespilia globules, dan Echinometra mathaei. D. setosum merupakan jenis bulu babi yang banyak ditemukan di 2 (dua) lokasi sampling yang berbeda yaitu 253 ind $/ 150 \mathrm{~m}^{2}$ pada stasiun A (rataan karang) dan $99 \mathrm{ind} / 150 \mathrm{~m}^{2}$ pada stasiun B (tubir karang) dengan persentase kelimpahan 59,390 \% pada stasiun A dan 51,295\% pada stasiun B. Jenis M. globules merupakan jenis bulu babi yang paling sedikit ditemukan di seluruh lokasi penelitian yang berjumlah 10 ind $/ 150 \mathrm{~m}^{2}$ pada stasiun $A$ dan1 ind/150 $\mathrm{m}^{2}$ pada stasiun $\mathrm{b}$ dengan persentase kelimpahan 2,347 \% pada stasiun A dan 0,518 \% pada stasiun B.

Persentase kelimpahan jenis bulu babi yang ditemukan pada seluruh stasiun (Stasiun A dan Stasiun B) tersaji pada Gambar 2 berikut: 


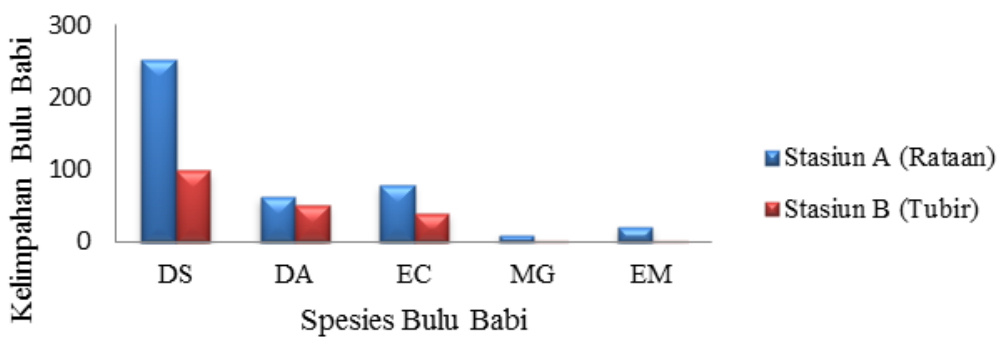

Keterangan:

Gambar 2. Histogram Kelimpahan Jenis Bulu Babi (Sea Urchin)

DS : D.Setosum

DA : D. antilarum

EC : E. calamaris

MG : M. globules

EM : E.mathaei

e. Nilai indeks keanekaragaman (H') dan keseragaman (e) ikan karang

Berdasarkan dari hasil penelitian, didapat nilai indeks keanekaragaman ( $\left.\mathrm{H}^{\prime}\right)$ dan indeks keseragaman (e) bulu babi (sea urchin) yang tersaji pada Tabel 3 berikut:

Tabel 3. Nilai Indeks Keanekaragaman (H') dan Indeks Keseragaman (e) Bulu Babi (Sea Urchin)

\begin{tabular}{cccc}
\hline No & Stasiun & H'$^{\prime}$ & $\mathrm{e}$ \\
\hline 1 & $\mathrm{~A}$ & 1,141 & 0,709 \\
2 & $\mathrm{~B}$ & 1,095 & 0,681 \\
\hline
\end{tabular}

Sumber: Data Penelitian 2013

f. Kelimpahan Jenis Bulu Babi (Sea Urchin) pada Karang Massive dan Karang Branching

Berdasarkan dari hasil penelitian, kelimpahan jenis bulu babi pada karang massive dan karang branching tersaji pada Tabel 4 berikut:

Tabel 4. Kelimpahan Jenis Bulu Babi (Sea Urchin) pada Karang Massive dan Karang Branching.

\begin{tabular}{cccccc}
\hline & & \multicolumn{4}{c}{ Tipe Karang } \\
\cline { 3 - 6 } No & Spesies & \multicolumn{2}{c}{ Karang Massive } & \multicolumn{2}{c}{ Karang Branching } \\
\cline { 3 - 6 } & & A & B & A & B \\
\hline 1 & Diadema setosum & 4 & 22 & 88 & 36 \\
2 & Diadema antilarum & 7 & 11 & 43 & 14 \\
3 & Echinothrix calamaris & 11 & 8 & 35 & 15 \\
4 & Mespillia globules & 3 & 0 & 7 & 0 \\
5 & Echinometra mathaei & 0 & 0 & 8 & 0 \\
\hline & Jumlah (ind/150 $\mathrm{m}^{2}$ ) & 25 & 41 & 118 & 65
\end{tabular}

Sumber: Data Penelitian 2013.

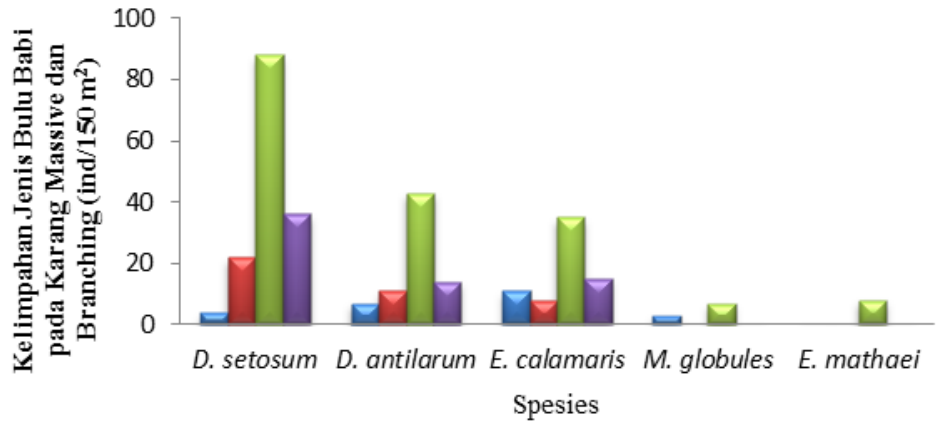

$\square$ Stasiun A (Massive)

- Stasiun B (Massive)

$\square$ Stasiun A (Branching)

- Stasiun B (Branching)

Gambar 3. Grafik Kelimpahan Jenis Bulu Babi (Sea Urchin) pada Karang Massive dan Karang Branching 


\section{g. Pengukuran Parameter Fisika dan Kimia}

Parameter fisika dan Kimia berperan penting dalam distribusi bulu babi (sea urchin). Berdasarkan hasil penelitian di Pantai Legon Boyo, parameter fisika dan kimia yang didapat tersaji pada Tabel 9 berikut:

Tabel 5. Parameter Fisika dan Kimia di Lokasi Penelitian.

\begin{tabular}{cccc}
\hline \multirow{2}{*}{ No. } & Parameter & \multicolumn{2}{c}{ Stasiun } \\
\cline { 3 - 4 } & & $\mathrm{A}$ & $\mathrm{B}$ \\
\hline 1. & Suhu Air $\left({ }^{\circ} \mathrm{C}\right)$ & $30-31$ & $28-30$ \\
2. & Suhu Udara $\left({ }^{\circ} \mathrm{C}\right)$ & $29-31$ & $27-28$ \\
3. & Kedalaman $(\mathrm{m})$ & $1,62-2,35$ & $3,20-4,77$ \\
4. & Salinitas $\left({ }^{\circ} \% 0\right.$ & $31-32$ & $30-31$ \\
5. & pH & 7 & 6 \\
6 & Kecerahan & 0 & 0 \\
7 & Kecepatan Arus $(\mathrm{m} / \mathrm{s})$ & $0,13-0,20$ & $0,08-1,02$ \\
\hline
\end{tabular}

Sumber: Data Penelitian 2013.

\section{Pembahasan}

\section{a. Persentase penutupan karang hidup pada daerah rataan dan daerah tubir}

Persentase penutupan karang hidup di stasiun A memiliki nilai sebesar $66,36 \%$ sedangkan pada stasiun $\mathrm{B}$, persentase penutupan karang hidup yang didapat adalah sebesar 73,00 \%. Kondisi dari kedua stasiun diatas termasuk ke dalam kategori karang dengan kondisi baik. Menurut Dahuri et al., (2001), dari nilai persentase penutupan karang hidup diatas termasuk ke dalam kategori karang dengan kondisi baik yaitu berkisar antara $50-75 \%$. Kondisi penutupan terumbu karang ini dipengaruhi oleh panjang tutupan karang yang ditemukan di lokasi penelitian. Kondisi penutupan karang yang masih baik memiliki nilai estetika tinggi yang dapat dijadikan sebagai kawasan pariwisata, kegiatan penelitian, serta sebagai ekosistem atau tempat hidup bagi banyak jenis-jenis ikan konsumsi yang berekonomis tinggi.

Menurut Supriharyono (2007), terumbu karang dengan kondisi yang baik juga akan memiliki produktivitas primer yang tinggi. Hal ini disebabkan karena terumbu karang memiliki kemampuan untuk menahan nutrien yang masuk ke dalam ekosistem tersebut serta karena adanya dukungan produksi dari sumber-sumber lain, seperti phytoplankton, lamun, mikro dan makroalga.

\section{b. Kelimpahan Jenis Bulu Babi}

Kelimpahan jenis bulu babi yang ditemukan di Pantai Legon Boyo berjumlah sebanyak 5 jenis, yaitu Diadema setosum, Diadema antilarum, Echinothrixcalamaris, Mespilia globules, dan Echinometra mathaei yang didapat di dua lokasi penelitian yaitu stasiun A (daerah rataan karang) dan stasiun B (daerah tubir karang). 5 (lima) jenis bulu babi yang ditemukan di stasiun A masing-masing yaitu: Diadema setosum sebanyak 253 individu/150 m², Diadema antilarum sebanyak 63 individu/150 m², Echinothrix calamaris sebanyak 79 individu/150 $\mathrm{m}^{2}$, Mespilia globules sebanyak 10 individu/150 $\mathrm{m}^{2}$, dan Echinometra mathaei sebanyak 21 individu/150 $\mathrm{m}^{2}$. Sedangkan pada stasiun B, juga ditemukan 5 jenis bulu babi, yaitu Diadema setosum sebanyak 108 individu/150 m², Diadema antilarum sebanyak 47 individu $/ 150 \mathrm{~m}^{2}$, Echinothrix calamaris sebanyak 35 individu/150 $\mathrm{m}^{2}$, Mespilia globules sebanyak 1 individu/150 $\mathrm{m}^{2}$, dan Echinometra mathaei sebanyak 2 individu/ $150 \mathrm{~m}^{2}$.

Data kelimpahan jenis bulu babi yang ditemukan selama penelitian dapat diolah untuk mengetahui nilai kelimpahan relatif tiap jenis, adapun Diadema setosum merupakan jenis bulu babi yang banyak ditemukan di lokasi penelitian dengan kelimpahan relatif pada stasiun A sebesar 59,390\% dan pada stasiun B sebesar $55,595 \%$.

D. setosum adalah salah satu dari jenis bulu babi yang hidup di ekosistem karang. Menurut Clark (1976), terumbu karang merupakan suatu ekosistem yang kompleks dan mempunyai nilai estetika yang tinggi, serta dihuni oleh berbagai jenis fauna, termasuk echinodermata yang merupakan penghuni terumbu karang yang cukup dominan.

Menurut Sugiarto dan Supardi (1995), D. setosum memiliki tempat hidup di ekosistem terumbu karang, dimana jenis ini bisa menempati rataan pasir, daerah pertumbuhan algae, pecahan karang dan karang mati, serta rataan karang dan daerah tubir karang. Bulu babi yang hidup di zona rataan pasir, daerah pertumbuhan algae, dan rataan karang biasanya hidup secara mengelompok dalam kelompok besar sedangkan di daerah tubir karang bulu babi ini hidup dalam kelompok kecil atau hidup menyendiri dalam lubang karang mati dan pecahan karang.

\section{c. Kelimpahan Jenis Bulu Babi (Sea Urchin) pada Karang Massive dan Karang Branching}

Berdasarkan dari hasil penelitian, kelimpahan jenis bulu babi yang ditemukan pada karang massive adalah sebesar 25 individu/150 $\mathrm{m}^{2}$ di stasiun A dan 41 individu/150 $\mathrm{m}^{2}$ di stasiun B. Sedangkan kelimpahan jenis bulu babi yang ditemukan pada karang branching adalah sebesar 182 individu/150 $\mathrm{m}^{2}$ di stasiun A dan 65 individu $/ 150 \mathrm{~m}^{2}$ yang terdapat di stasiun $\mathrm{B}$. 
Dari hasil diatas, dapat dilihat bahwa kelimpahan bulu babi paling banyak ditemukan secara berkelompok di daerah karang bercabang (branching) dan pecahan karang, dan bulu babi paling sedikit ditemukan di daerah karang massive dan pasir. Jadi, dapat diasumsikan bahwa bulu babi (sea urchin) lebih menyukai hidup di daerah karang bercabang serta pecahan karang karena di daerah tersebut terdapat banyak makanan bagi bulu babi dan tempat untuk berlindung bulu babi dari predator yang menyerang.

Menurut Sugiarto dan Supardi (1995), di daerah ekosistem terumbu karang, bulu babi biasanya menempati daerah rataan karang, daerah pertumbuhan algae dan daerah tubir karang. Di zona rataan karang dan daerah pertumbuhan algae, bulu babi biasanya hidup secara mengelompok dalam kelompok yang besar.

Sedangkan menurut Vimono (2007), bulu babi seringkali ditemukan pada habitat yang spesifik, seperti daerah rataan, daerah lamun, dan daerah pertumbuhan algae. Bulu babi biasanya ditemukan pada habitat yang spesifik, namun beberapa jenis mampu hidup pada daerah yang berbeda. Echinometra mathaei adalah salah satu jenis bulu babi yang hanya dijumpai di celah-celah bebatuan atau pecahan karang. Berbeda dengan jenis dari $D$. setosum yang dapat ditemukan pada hampir semua daerah mulai dari rataan pasir, padang lamun, rataan karang dan tubir, hingga ke daerah bebatuan.

\section{d. Analisis Uji Independent T Test dengan SPSS}

Berdasarkan dari hasil perhitungan kelimpahan jenis bulu babi pada karang massive dan branching di dua lokasi berbeda (daerah rataan dan tubir karang), dapat disimpulkan bahwa data kelimpahan bulu babi yang ditemukan pada karang massive berbeda dengan data kelimpahan bulu babi yang ditemukan pada karang branching. Hal ini dikarenakan nilai Signifikan-nya adalah 0,008 sehingga $0,008 \leq 0,05$. Hal ini berarti bahwa $\mathrm{H}_{1}$ diterima sehingga dapat diasumsikan bahwa terdapat perbedaan pada jumlah bulu babi pada karang massive dan karang branching.

\section{e. Parameter fisika dan kimia}

Bagi biota perairan, kualitas air (fisika, kimia, biologi) memiliki peran penting dalam proses hidupnya. Bagi bulu babi dan hewan karang, kualitas air sangat berpengaruh dalam pemijahan, distribusi, kelimpahan, adaptasi lingkungan, dan dalam mencari makan. Parameter kualitas air yang diukur dalam penelitian ini adalah kecerahan, kedalaman, suhu, salinitas, dan $\mathrm{pH}$ air.

Kecerahan yang didapat di stasiun A dan stasiun B adalah 0 (nol). Hal ini berarti bahwa dasar perairan masih dapat terlihat dengan jelas dari permukaan. Pernyataan ini diperkuat oleh Hutabarat dan Stewart (2000) yang menyatakan bahwa pada perairan yang dalam dan jernih, proses fotosintesis dan penetrasi cahaya hanya dapat sampai kedalaman sekitar 200 meter.

Menurut Ghufran et al., (2007), dengan mengetahui kecerahan suatu perairan, kita dapat mengetahui sampai dimana masih ada kemungkinan proses asimilasi dalam air, lapisan-lapisan manakah yang jernih, yang agak keruh, dan yang paling keruh. Air tidak terlampau keruh dan tidak pula terlampau jernih baik untuk kehidupan biota perairan.

Kedalaman yang didapat di lokasi penelitian yaitu pada stasiun A berkisar antara 1,62 - 2,35 meter dan pada stasiun B berkisar antara 3,20 - 4,77 meter. Kedalaman memiliki peran terhadap masuknya penetrasi cahaya ke badan air, apabila semakin dalam suatu perairan, maka semakin cepat pula penurunan intensitas cahaya yang masuk ke badan air. Cahaya diperlukan oleh phytoplankton dan tumbuhan air untuk berfotosintesis, sehingga apabila semakin dalam suatu perairan maka intensitas cahaya yang masuk juga akan berkurang dan penyebaran phytoplankton dan tumbuhan juga akan berkurang.

Kedalaman suatu perairan akan mempengaruhi kelimpahan organisme yang termasuk didalamnya yaitu bulu babi. Secara umum bulu babi dapat ditemukan di daerah intertidal yang relatif dangkal dan jumlahnya akan semakin menurun apabila kedalaman perairan tersebut semakin meningkat. Hal ini dikarenakan pada perairan yang dalam, bahan-bahan organik yang terkandung didalamnya sedikit, maka produktivitas perairan diatasnya juga berkurang, sehingga kepadatan organismenya, termasuk bulu babi juga rendah (Aziz, 1993).

Salinitas yang didapat pada lokasi penelitian di stasiun A yaitu sebesar $31 \%$, sedangkan pada stasiun B salinitas yang didapat adalah sebesar $30 \%$. Nilai salinitas di stasiun B lebih rendah daripada stasiun A dikarenakan pelaksanaan sampling di stasiun B dilaksanakan setelah hujan.

Menurut Aziz (1994), bulu babi secara umum seperti fauna echinodermata lainnya, tidak tahan terhadap salinitas rendah. Kecuali untuk jenis yang hidup di daerah pasang surut, yaitu bulu babi jenis Strongylocentrus purpuratus yang hidup di daerah pasang surut relative tahan terhadap pengenceran salinitas pada saat musim hujan. Kisaran salinitas di suatu perairan berkisar antara $23 \%$ - $26 \%$, maka akan berakibat pada perubahan pigmen warna, duri-duri akan rontok, dan bulu babi akan menjadi tidak aktif, tidak mau makan, dan pada akhirnya akan mengalami kematian setelah beberapa hari.

Suhu air dan suhu udara yang didapat di lokasi penelitian adalah pada stasiun A suhu air berkisar antara $30-31{ }^{\circ} \mathrm{C}$ dan suhu udara berkisar antara $29-31{ }^{\circ} \mathrm{C}$, sedangkan pada stasiun B suhu air berkisar antara $28-$ $30{ }^{\circ} \mathrm{C}$ dan suhu udara berkisar antara $27-28{ }^{\circ} \mathrm{C}$. Perbedaan suhu air dan udara pada tiap stasiun dikarenakan oleh suhu air pada stasiun A lebih tinggi karena terdapat di daerah rataan dengan kedalaman yang berkisar antara $1-2$ meter sedangkan di stasiun B terdapat di daerah tubir dengan kedalaman yang berkisar antara $3-$ 
4 meter dan suhu udara pada stasiun A lebih tinggi karena cuaca di lokasi pada saat sampling cerah sedangkan pada stasiun B suhu udara lebih rendah karena kegiatan sampling dilaksanakan ketika cuaca mendung dan hujan.

Menurut Aziz (1988), Bulu babi mempunyai kebiasaan hidup mengelompok atau beragregasi dan hewan ini seringkali terperangkap di daerah rataan terumbu pada saat surut purnama. Berbeda dengan kelompok teripang dan bintang ular, jenis-jenis bulu babi tidak tidak mengenal cara adaptasi khusus untuk menghindari sengatan matahari. Kelompok inilah yang paling banyak dilaporkan mengalami kematian massal akibat suhu ekstrim di atas ambang batas.

Menurut Tsuchiya et al., (1987), Jenis Echinometra mathaei akan mengalami kematian pada suhu $35^{\circ} \mathrm{C}$ dalam waktu 12 jam, Sedangkan di alam hewan ini dilaporkan mengalami kematian massal pada suhu $36^{\circ} \mathrm{C}$ sampai $40^{\circ} \mathrm{C}$.

Menurut Hutagalung (1988), Suhu air dapat juga mempengaruhi perkembangan embrionik. Sebagai contoh perkembangan embrionik bulu babi Strongylocentrotus drobacchiensis menjadi tidak normal apabila suhu air naik melebihi $11^{\circ} \mathrm{C}$.

Kecepatan arus yang didapat di lokasi penelitian adalah $0,13-0,20 \mathrm{~m} / \mathrm{s}$ pada stasiun A dan $0,08-1,02$ $\mathrm{m} / \mathrm{s}$. Dari hasil tersebut dapat diasumsikan bahwa kecepatan arus yang ditemukan di stasiun A lebih rendah daripada stasiun B. Pengukuran kecepatan arus di stasiun B dilakukan ketika kondisi alam sedang mengalami angin kencang dan hujan. Menurut Supriharyono (2009), kecepatan arus yang terdapat di perairan laut berkisar antara $2-5 \mathrm{~m} / \mathrm{s}$. Kecepatan arus selain dipengaruhi oleh angin, juga dipengaruhi oleh kondisi alam seperti hujan dan perubahan suhu perairan.

\section{Kesimpulan}

Kesimpulan yang dapat diambil dari penelitian Kelimpahan Bulu Babi (Sea Urchin) pada Karang Massive dan Branching di Daerah Rataan dan Tubir di Pantai Legon Boyo, Pulau Karimunjawa, Taman Nasional Karimunjawa adalah Kelimpahan jenis bulu babi yang terdapat pada karang branching yaitu sebesar 181 individu/ $150 \mathrm{~m}^{2}$ di stasiun A (daerah rataan) dan 65 individu/ $150 \mathrm{~m}^{2}$ di stasiun B (daerah tubir). Adapun kelimpahan bulu babi pada karang massive adalah sebesar 24 individu/ $150 \mathrm{~m}^{2}$ di stasiun A (daerah rataan) dan 41 individu/ $150 \mathrm{~m}^{2}$ di stasiun B (daerah tubir). Jumlah total kelimpahan bulu babi di stasiun A (daerah rataan) adalah sebesar 426 individu/ $150 \mathrm{~m}^{2}$ dan pada stasiun B (daerah tubir) adalah sebesar 193 individu/ $150 \mathrm{~m}^{2}$.

\section{Ucapan Terima Kasih}

Penulis mengucapkan terimakasih kepada Dr. Ir. Suryanti, M.Pi dan Churun A'in, S.Pi, M.Si atas bimbingan dan arahannya dalam penyusunan jurnal ini.

\section{Daftar Pustaka}

Aziz, A. 1988. Pengaruh Tekanan Panas Terhadap Fauna Ekhinodermata. Oseana 13 (3): 125 - 132.

1993. Beberapa Catatan Tentang Perikanan Bulu Babi. Oseana 18 (2): 65 - 75.

1994. Pengaruh Salinitas Terhadap Sebaran Fauna Ekhinodermata. Oseana 19 (2): 23 - 32.

1994a. Tingkah Laku Bulu Babi di Padang Lamun. Oseana 19 (4): 35 - 43.

Clark, A. M. 1976. Echinoderm of coral reefs, In : O.A. Jones \& R. Endean (eds) Geology and Ecology of Coral Reefs. 3. Acad. Press, New York : $95-123$.

Carpenter, E. Kent., Volker, H. Niem. 1998. The Living Marine Resources of the Western Central Pacific. Vol 1. Seaweeds, Corals, Bivalves, and Gastropods. Pp. 1 - 686: Rome.

Dahuri, R., J. Rais., S. P. Ginting, dan M. J. Sitepu. 2001. Pengelolaan Sumberdaya Wilayah Pesisir dan Lautan Secara Terpadu. PT. Paradnya Paramita: Jakarta.

Ghufran, M. H., Kordi. K., Andi B. T. 2007. Pengelolaan Kualitas Air dalam Budidaya Perairan. Rineka Cipta: Jakarta.

Hartono. 2008. Analisis Data Statistika dan Penelitian. Pustaka Pelajar: Yogyakarta.

Hutabarat, S., Stewart M. Evans. 2000. Pengantar Oseanografi. Penerbit Universitas Indonesia (UI Press): Jakarta.

Hutagalung, H. P. 1988. Pengaruh Suhu Air Terhadap Kehidupan Organisme Laut. Oseana 13 (4): 153 -164.

Lalamentik, L. T. X., dan U. N. W. J. Rembet. 1996. Penilaian Kondisi Terumbu Karang dengan Penekanan pada Batu Karang. Metodologi Penelitian Terumbu Karang. P3O LIPI Sumberdaya Ambon dan Fakultas Perikanan Unsrat: Manado.

Nybakken, J. W. 1992. Biologi Laut, Suatu Pendekatan Ekologis. PT Gramedia Pustaka: Jakarta.

Nyström, M., C. Folke., F. Moberg. 2000. Coral Reef Disturbance and Resilience in A Human-Dominated Environment. Trends in Ecology and Evolution.

Odum, E. P. 1993. Dasar-dasar Ekologi. Fundamental of Ecology. Gajah Mada University Press: Yogyakarta. 
Rahman, E. A. Puji, P. Mulyadi. R, Sulisyati. Hary, S. Limaryadi. Zaenul, A. M, S, J, E, Mardiko. 2010. Buku Panduan Identifikasi Jenis Terumbu Karang di Taman Nasional Karimunjawa. Balai Taman Nasional Karimunjawa; semarang. 54 halaman.

Sugiarto, H. dan Supardi. 1995. Beberapa Catatan Tentang Bulu Babi Marga Diadema. Oseana 20 (4): $35-41$.

Supriharyono. 2007. Konservasi Ekosistem Sumberdaya Hayati di Wilayah Pesisir dan Laut Tropis. Pustaka Pelajar: Yogyakarta.

2009. Pengelolaan Ekosistem Terumbu Karang. Djambatan: Jakarta

Tsuchiya, M., K. Yanagiya. and M. Nishihira. 1987. Mass Mortality of the Sea Urchin Echinometra mathaei (Blain- Ville) Caused by High Water Temperature on the Reef Flats in Okinawa, Japan. Galaxea 6: 375 -385 .

WCS (Wildlife Conservation Society) Marine Program Indonesia. 2004. Laporan Teknis Wildlife Conservation Society Asia Pacific Coral Reef Program Indonesia Survei 2003-2004 di Kepulauan Karimunjawa, Jawa Tengah. Wildlife Conservation Society Asia Pacific Coral Reef Program Indonesia: Bogor. $66 \mathrm{hlm}$.

Vimono, I. B. 2007. Sekilas Mengenai Landak Laut. Oseana, Volume 20 (3). 37 - 46. 